\title{
Extraskeletal myxoid chondrosarcoma
}

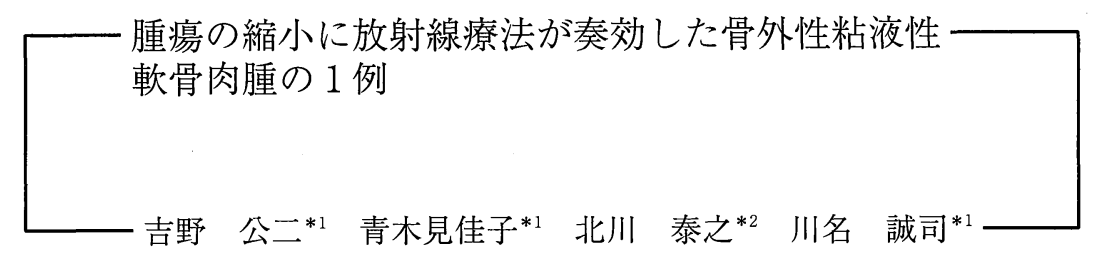

\section{Extraskeletal myxoid chondrosarcoma \\ Koji YOSHINO *1, Mikako AOKI *1, Yasuyuki KITAGAWA *2, Seiji KAWANA *1 \\ ${ }^{* 1}$ Department of Dermatology, Nippon Medical School \\ *2 Department of Orthopedics, Nippon Medical School}

We reported a case of a 51-year-old man of extraskeletal myxoid chondrosarcoma. Thirteen years ago, he noticed a slowly progressive subcutaneous tumor of the right inguinal region. Aspiration biopsy was done resulting in a diagnosis of extraskeletal myxoid chondrosarcoma.

We found lung metastasis. In general, the treatment for extraskeletal myxoid chondrosarcoma is an operation, chemotherapy and radiation therapy. However, this patient only received radiation therapy for the inguinal subcutaneous tumor. One year later, the subcutaneous tumor had disappeared. [Skin Cancer (Japan) 2002 ; 17:279-282]

Key words: Extraskeletal myxoid chondrosarcoma, Radiation therapy

\section{はじめに}

骨外性粘液性軟骨肉腫は比較的稀で，術前診 断が難しい軟部悪性腫瘍である。今回我々は細 胞診で暫定診断がつき，更に放射線療法で腫瘍 の著しい縮小を認めた症例を経験したので報告 する。

\section{症例}

患 者: 51 歳, 男性, 陶芸家

\section{*1 日本医科大学皮膚科学教室}

$* 2$ 同整形外科
初 診：平成 13 年 3 月 16 日

主 訴: 右鼠径部腫瘤

現病歴：初診の 13 年前に, 右鼠径部に腫瘤を 自覚したが放置していた。その 3 年後, 他医に て鶏卵大に腫大した腫瘤を摘出し, 病理組織学 診断は Myxoid lipoasarcoma であったが，患者 の希望により無治療で経過観察となった。その 後平成 8 年頃から再び同部位に腫瘤が出現し た。平成 12 年某大学病院で, 再発および肺転移 を指摘されたが治療を拒否し，平成 13 年 3 月, 当科を受診した。

初診時：右鼠径部に $16 \times 14 \times 6.5 \mathrm{~cm}$ の常色お よび一部淡褐色の色素沈着を伴う表面平滑, 多 房性, 弾性軟の腫瘤を認めた（図 1 )。脂肪肉腫 
などの間葉系悪性腫瘍を疑い，鼠径部腫瘤の生 検および細胞診を施行した。

細胞診所見：パパニコロウ染色で青色の myxoid な間質の中に小型の核小体を有する異 型性の乏しい腫瘍細胞が索状に配列する像が得 られ, lipoblast も認められないことから骨外性 粘液性軟骨肉腫と診断した（図２）。

病理組織所見 : 粘液基質を背景に卵円形で異 型性に乏しい核を持ち, 細胞質に乏しい腫瘍細 胞が索状ないし充実性に増殖している所見を認 めた（図 3 )。

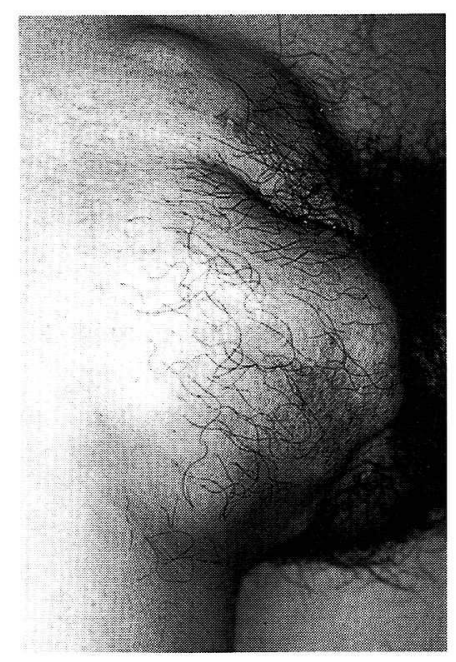

図 1. 初診時臨床写真

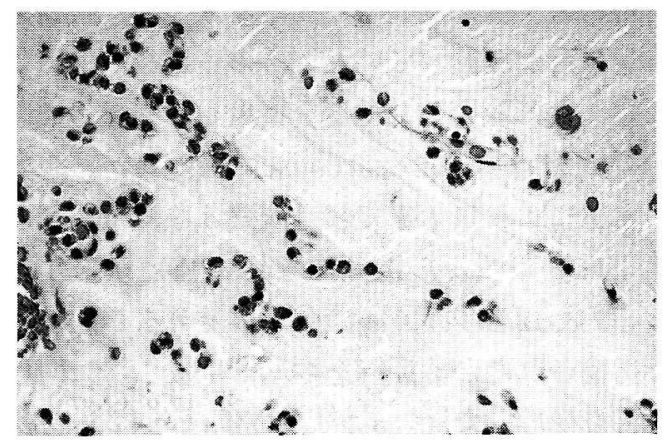

図 3.病理組織所見

H.E. 像では, 粘液基質を背景に卵円形で異 型性に乏しい核を持ち，細胞質にそしい腫韵 細胞を認める
画像所見：MRIにおいて, 右鼠径部に $15 \times 15$ $\times 10 \mathrm{~cm}$ の境界明暸で内部不均一な多房性の腫 瘤を認める。大腿動静脈に近接し陰囊, 陰茎へ の浸潤も認めるが，尿道，前立腺は保たれてい る。隔壁様の部分は T1 強調画像で high intensity, T2 強調画像で low intensity を呈し, 内部は T1 強調画像で low intensity, T2 強調画 像で high intensityであることより画像上骨外 性粘液性軟骨肉腫が考えられた（図４）。血管造 影検查では腫瘍自体は血流にそしく，支配血管 は内腸骨, 外腸骨動脈の二重支配を受けている。

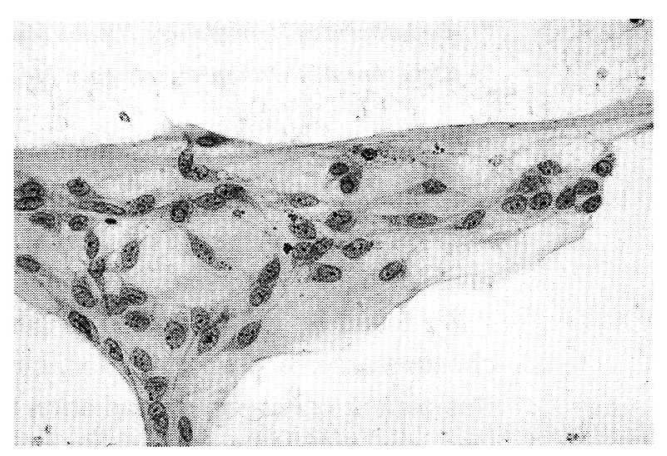

図 2. 細胞診所見 パパニコロウ染色で青色の myxoid な間質の 中に小型の核小体を有する腫瘍細胞が索状に 配列する

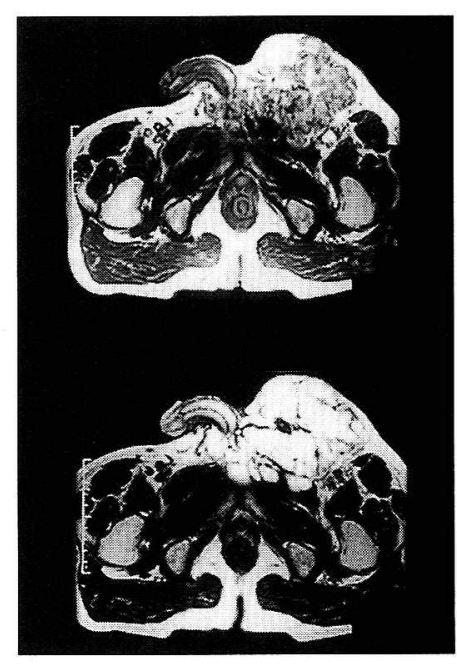

図 4.MRI 画像（T1 およびT2 強調画像 放射線 照射前) 


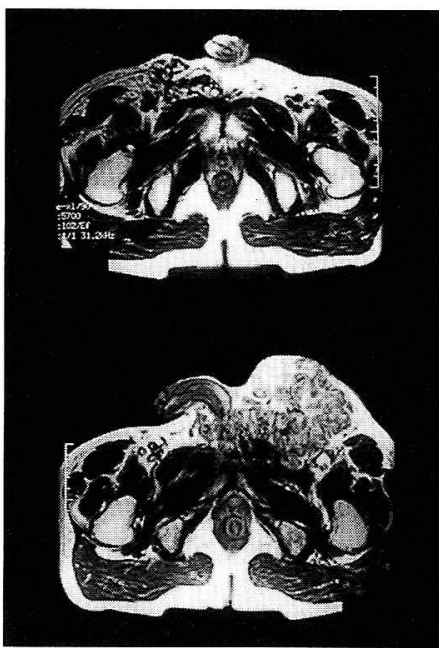

図 5.MRI 画像（放射線照射前後）

また胸部単純 X-P およびCTでは両側肺野に $1 \mathrm{~cm}$ 大の腫瘤が多数認められ，肺転移と思われ た。以上，組織学的㧍よび画像所見より，肺転 移を伴う右鼠径軟部原発の骨外性粘液性軟骨肉 腫と診断した。

入院後経過：外科的切除の適応について整形 外科, 泌尿器科とともに検討したが排尿機能, 性機能への侵襲が大きいため, 術前にリニアッ クによる放射線療法を開始した。1 回 2Gray で 計 19 回，合計 38Gray を施行。照射直後は腫瘤 は縮小しなかったが，その後緩徐に縮小を認め 8 力月後には $5 \times 2 \times 5 \mathrm{~cm}$ と縮小し， 1 年後に は表面への突出はほぼなくなり $4 \times 2 \times 3 \mathrm{~cm}$ の 皮下腫瘤になっている(図 5，6)。残存してい る腫瘍の摘出および肺転移に対する化学療法を 勧めたが, 拒否され無治療で経過観察中である。

\section{考察}

骨外性粘液性軟骨肉腫は比較的稀な軟部腫瘍 であり，好発年齢は 40 50 歳代で，好発部位は 大腿抢よび膝窝で全体の約 $70 \%$ ，皮下，筋肉内 いずれにも発生する ${ }^{1)}$ 。他の軟部悪性腫瘍と比 較し緩徐な発育を示す低悪性腫瘍であり ${ }^{2)}$, 今 回の症例でも腫瘤の発生から 13 年が経過し, 肺

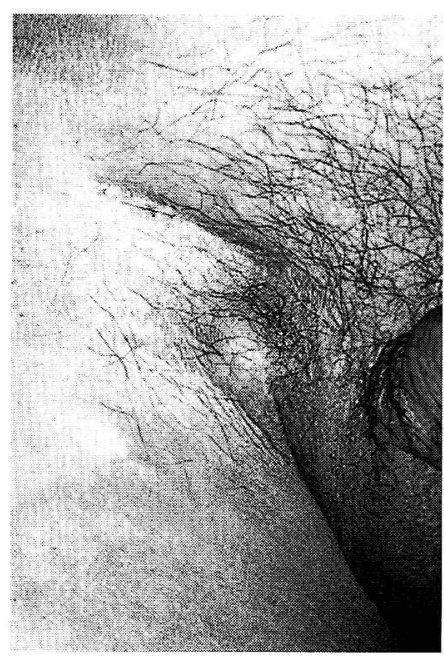

図 6. 照射 1 年後臨床写真

転移も出現しているが，患者は通常の日常生活 を継続している。

本疾患は細胞診で myxoid な間質の中に小型 の核小体を有する異型性のそしい腫瘍細胞が索 状に配列する特徵的な像を呈することが知られ ており ${ }^{3)}$ ，自験例でも生検翌日細胞診で暫定診 断がついた。組織学的鑑別診断は，粘液状基質 の中に小型の腫瘍細胞が索状に配列する特徴を 持つ粘液型脂肪肉腫, 悪性線維性組織球腫など が考えられた。

治療は原則的には外科的治療で放射線および 化学療法に対する感受性は一般的に低いと言わ れている4)。しかし本症例では $15 \times 15 \times 10 \mathrm{~cm}$ と巨大腫瘤であるにも関わらず合計 $38 \mathrm{Gray}$ を 施行 8 力月後には $5 \times 2 \mathrm{~cm}$ に縮小した。照射後， 約 1 年が経過しているが現在も緩徐に縮小を続 けている。

本症例において，放射線療法が奏功した理由 は不明であるが, myxoidな間質が大部分を占め る本疾患ではたとえ放射線療法が有効な症例で あっても粘液様物質が吸収されるのに時間がか かるため，実際の腫瘤の縮小には照射後数力月 を待つ必要があるかもしれない。本症例では患 者が他の治療を拒否したため経過観察のみ行っ たところ，照射後 1 年にわたって緩徐な縮小が 
続き, 結果的には放射線療法は高い有効性を示 した。放射線感受性は一般に低いと言われてる が, 本疾患における放射線療法の有効性の判断 は，放射線療法後数力月を待って行うべきかと 考える。

遠隔転移に対して化学療法を行うことがあ り，様々な薬剤が使用されている。特定のプロ トコールはないが，CDDP と ADM にて腫瘍の 縮小がみられたとの報告がある ${ }^{5 !}$ 。免疫療法で は Interferon alfa-2b を使用することにより，著 効を示したとの報告も認められる ${ }^{6)}$ 。

\section{文献}

1）石和万美子ら：骨外性粘液性軟骨肉腫の 1 例。日 皮会誌，105 巻：1769-1775, 1995

2）神野哲也ら：骨外性粘液性軟骨肉腫の 2 例. 整形 外科, 43 巻 : 201-206, 1992

3 ) Enzinger FM, Weiss SW : Soft tissue tumors. 4rd ed, CV Mosby, St.Louis, 2001, p1368-1385

4) 佐々木真弓ら：放射線, 動注, 温熱療法同時併用 が著効した骨外性粘液性軟骨肉腫の 1 例. J Jpn Soc Cancer Ther, 32 巻 : 55-59, 1997

5）山本正洋ら：化学療法が肺転移に著効を示した骨 外性粘液性軟骨肉腫の 1 例.東北整災紀要, 31 巻： 182, 1987

6) Rubinger $M$, et al : Metastatic extraskeletal myxoidsarcoma Successful therapy with interferon alfa-2b. Chest, 108:281-282 